\title{
Effect of Organic and Inorganic Nutrient Sources on Yield, Quality and Nutrient Uptake by Cabbage (Brassica oleracea L. var capitata) in Acid Inceptisol
}

\author{
Chingak P.W. Konyak and Sanjay-Swami* \\ School of Natural Resource Management, College of Post Graduate Studies, \\ Central Agricultural University, Umiam-793103, Meghalaya, India \\ *Corresponding author
}

\section{Keywords}

Nutrient sources, Inorganic, Organic, Cabbage, yield, quality and acid soil

Article Info

Accepted:

24 June 2018

Available Online:

10 July 2018

\section{A B S T R A C T}

A field experiment was conducted during rabi 2017-18 to study the effect of various organic and inorganic nutrient sources on yield, quality and uptake of nutrient by cabbage (Brassica oleracea L. var capitata) in acid inceptisol of Meghalaya with eight treatment combinations viz. control $\left(\mathrm{T}_{1}\right), 100 \%$ RDF $\left(\mathrm{T}_{2}\right), 100 \% \mathrm{~N} \mathrm{FYM}\left(\mathrm{T}_{3}\right), 100 \% \mathrm{~N}$ VC $\left(\mathrm{T}_{4}\right), 50 \%$ $\mathrm{RDF}+50 \% \mathrm{~N} \mathrm{FYM}\left(\mathrm{T}_{5}\right), 75 \% \mathrm{RDF}+25 \% \mathrm{~N} \mathrm{FYM}\left(\mathrm{T}_{6}\right), 50 \% \mathrm{RDF}+50 \% \mathrm{~N} \mathrm{VC}\left(\mathrm{T}_{7}\right)$ and $75 \% \mathrm{RDF}+25 \% \mathrm{~N} \mathrm{VC}\left(\mathrm{T}_{8}\right)$. The experiment was laid out in RBD and replicated thrice. The experimental soil was having $\mathrm{pH} 4.87$, SOC (\%) 1.24, Alkaline $\mathrm{KMnO}_{4^{-}} \mathrm{N} 160$ (kg/ha), available $\mathrm{P}_{2} \mathrm{O}_{5} 18.60(\mathrm{~kg} / \mathrm{ha})$ and available $\mathrm{K}_{2} \mathrm{O} 238.4(\mathrm{~kg} / \mathrm{ha})$. The experimental results revealed that treatment $\mathrm{T}_{7}$ of $50 \% \mathrm{RDF}+50 \% \mathrm{~N}$ VC produced highest cabbage yield (60.44t/ha) which was statistically comparable with $\mathrm{T}_{5}$ of $50 \% \mathrm{RDF}+50 \% \mathrm{~N} \mathrm{FYM}$ (54.33 t/ha). The yield obtained in $\mathrm{T}_{5}$ was almost same as obtained with $100 \% \mathrm{RDF}$ alone $\left(\mathrm{T}_{2}\right)$. The quality of cabbage with respect to head compactness, head shape index was also followed the same trend. Moreover, concentration and uptake of N, P, and K were also superior in $\mathrm{T}_{7}$ indicating best suitable option for production of quality cabbage in acid inceptisol of Meghalaya.

\section{Introduction}

The benefits of increased use of fertilizers in achieving targets of food grain production are well reported, however the major crop-based production systems have started showing symptoms of decline in productivity (Chaudhari, 2016). Cabbage is known to play predominant role in Indian meal as it possess high nutritive value supplying essential vitamins, proteins, carbohydrates and vital minerals amongst cruciferaceae. However, productivity of cabbage in our country stands with just $22.6 \mathrm{t} / \mathrm{ha}$ which is far behind other developed countries, where as Meghalaya stands with just $21.57 \mathrm{t} / \mathrm{ha}$ (Indian Horticulture Database, 2014). The food demand is on the increase, the factor productivity and rate of response of crops to applied fertilizers under intensive farming conditions are continuously declining with every passing year. Major reasons for soil fertility deterioration include 
wide gap between nutrient demand and supply, high nutrient turnover in soil-plant system coupled with low and imbalanced fertilizer use, emerging deficiencies of secondary and micronutrients, rise of soil acidity, and nutrient immobilization in clayey soils. The problem is more severe under acidic soils which are under intensive cropping. However, the viable option lies on maintaining soil health to increase in fertilizer use to achieve sustainable agriculture. Soil organic matter (SOM) plays a key role in soil fertility sustenance. Association of organic matter and nutrient availability has been confirmed by the high coefficients of correlation between the soil attributes (Sakal et al., 1996) and use of chemical fertilizers in combination with organic manure is essentially required to improve soil health (Bajpai et al., 2016). Therefore, the present investigation was carried out to study the effect of vermicompost, FYM, inorganic fertilizers and integrated nutrient management on yield, quality and nutrient uptake of cabbage in inceptisol of Meghalaya.

\section{Materials and Methods}

The experiment was conducted on the farmer's field near ICAR Research Complex for NEH Region, Umiam $\left(91^{\circ} 18^{\prime}\right.$ E longitude and $25^{\circ} 40^{\prime} \mathrm{N}$ latitude and at an altitude of 950 $\mathrm{m}$ above the mean sea level). The experimental soil was having $\mathrm{pH} 4.87$, SOC (\%) 1.24, Alkaline $\mathrm{KMnO}_{4^{-}} \mathrm{N} 160$ (kg/ha), available $\mathrm{P}_{2} \mathrm{O}_{5} 18.60(\mathrm{~kg} / \mathrm{ha})$ and available $\mathrm{K}_{2} \mathrm{O} 238.4$ (kg/ha). The experiment was conducted in Randomized Block Design (RBD) having eight treatments and three replications viz., control $\left(\mathrm{T}_{1}\right), 100 \% \mathrm{RDF}\left(\mathrm{T}_{2}\right)$, $100 \%$ N FYM $\left(\mathrm{T}_{3}\right), 100 \% \mathrm{~N}$ VC $\left(\mathrm{T}_{4}\right), 50 \%$ $\mathrm{RDF}+50 \% \mathrm{~N} F Y M\left(\mathrm{~T}_{5}\right), 75 \% \mathrm{RDF}+25 \% \mathrm{~N}$ FYM $\left(\mathrm{T}_{6}\right), 50 \% \mathrm{RDF}+50 \% \mathrm{~N} \mathrm{VC}\left(\mathrm{T}_{7}\right)$ and $75 \% \mathrm{RDF}+25 \% \mathrm{~N} \mathrm{VC}\left(\mathrm{T}_{8}\right)$ and replicated thrice. All the agronomic practices were followed for raising cabbage. The nutrient content in FYM in dry weight basis was $\mathrm{N}(\%)$
$0.55, \mathrm{P}(\%) 0.24$ and $\mathrm{K}(\%) 0.34$ while in vermicompost $\mathrm{N}(\%) 2.10, \mathrm{P}(\%) 1.22$ and $\mathrm{K}$ (\%) 1.53, respectively.

Head shape index was generated by transverse ratio of transverse and longitudinal and head compactness was obtained as per the Z-value (Pearson, 1931). N, P and K uptake was determined with the help of their content and dry matter yield of cabbage. The data recorded for various parameters were analyzed statistically by following procedure of Gomez and Gomez (1984).

\section{Results and Discussion}

\section{Head shape index (HSI)}

The effect of different treatments on head shape index (HSI) in between and within the treatments were negligible (Table 1). As a result, the data was statistically non-significant $(P \leq 0.05$, one-way ANOVA). However, small variations were recorded due to different treatments. Head shape was recorded ranging from 0.96 in $\mathrm{T}_{1}$ (control) to 0.98 in $\mathrm{T}_{4}(100 \%$ $\mathrm{N}$ VC) which indicated a better head shape in $\mathrm{T}_{4}$. It was consequently followed by $\mathrm{T}_{3}(100 \%$ $\mathrm{N}$ FYM) and $\mathrm{T}_{4}(50 \% \mathrm{RDF}+50 \% \mathrm{VC})$ which was statistically at par. Interestingly, all the organic manure sole and combined treatments showed higher HSI over $\mathrm{T}_{2}(100 \%$ RDF treatment) and $\mathrm{T}_{1}$ (control treatment). It was found that head shape index was positively correlated $\left(\mathrm{R}^{2}=0.494\right)$ with net weight of cabbage. Therefore, head shape index could also be apparently indicated by the net weight of cabbage. The lower HSI value may be inferred that flat or drum head type was not desirable from the view points of market and consumers. The above finding reveals that HSI value might be duly influence by different nutrient treatment and concentration in the soil. This finding was in concurrent with the finding of Singh et al., (2010) and Mohanty (1998). 


\section{Head compactness}

It was generated on the basis of Z-value of head compactness as per the method of Pearson (1931).The highest head compactness was recorded with the $\mathrm{T}_{7}-50 \% \mathrm{RDF}+50 \% \mathrm{~N}$ $\mathrm{VC}$ treatment i.e. 10.89 which increase the head compactness by 75.08 per cent over control (Table 1). Application of sole organic manure numerically exceeded in head compactness over the sole application of inorganic fertilizer but statistically at par with each other. The treatments $\mathrm{T}_{5}, \mathrm{~T}_{6}, \mathrm{~T}_{7}$ and $\mathrm{T}_{8}$ were statistically at par with $\mathrm{T}_{2}-100 \% \mathrm{RDF}$ which clearly indicates that dose of chemical fertilizer could be minimized with 25-50 per cent of organic manures. This might be due to effects of bridging the nutrient supply with demand of cabbage during growth and development in combined treatments $\left(T_{7}, T_{5}\right.$, $\mathrm{T}_{6}$ and $\mathrm{T}_{8}$ ) of farm yard manure and vermicompost along with inorganic nutrient source. The relative effectiveness of different nutrient sources in head compactness of cabbage could be stated as: chemical fertilizers< Organic sources < integrated sources. A similar finding had been reported by Pande and Singh (2015).

\section{Head yield}

The cabbage head yield data showed that maximum head yield of cabbage was found in treatment $\mathrm{T}_{7}(50 \% \mathrm{RDF}+50 \% \quad \mathrm{~N} \quad \mathrm{VC})$ as presented in table 1 . The per cent increase in $\mathrm{T}_{7}$ over $\mathrm{T}_{2}(100 \% \mathrm{RDF})$ was 12.02 per cent. However, it was at par with other treatments viz., $\mathrm{T}_{3}, \mathrm{~T}_{4}, \mathrm{~T}_{5}, \mathrm{~T}_{6}, \mathrm{~T}_{7}$ and $\mathrm{T}_{8}$. The integration of vermicompost and FYM increased head yield over RDF (120:60:60), reflecting their fertilizer use efficiency in terms of head yield. The higher yield in combined treatments $\left(\mathrm{T}_{7}\right.$, $\mathrm{T}_{5}, \mathrm{~T}_{6}$ and $\mathrm{T}_{8}$ ) might be due to favourable soil condition and synchronized released of nutrients throughout the crop growth period (Murali and Setty, 2004).

Table.1 Effect of organic and inorganic nutrient sources on Head Shape Index, Cabbage Head Compactness and head yield of cabbage (Brassica oleracea $\mathrm{L}$. var capitata) in acid inceptisol

\begin{tabular}{|c|c|c|c|}
\hline Treatments & Head compactness & Head shape Index & Yield t/ha \\
\hline $\mathbf{T}_{\mathbf{1}}$ & 6.228 & 0.960 & 34.26 \\
\hline $\mathbf{T}_{\mathbf{2}}$ & 7.228 & 0.964 & 53.92 \\
\hline $\mathbf{T}_{\mathbf{3}}$ & 7.555 & 0.971 & 44.97 \\
\hline $\mathbf{T}_{\mathbf{4}}$ & 8.808 & 0.974 & 47.18 \\
\hline $\mathbf{T}_{\mathbf{5}}$ & 9.688 & 0.977 & 54.33 \\
\hline $\mathbf{T}_{\mathbf{6}}$ & 9.221 & 0.971 & 48.79 \\
\hline $\mathbf{T}_{\mathbf{7}}$ & 10.892 & 0.980 & 60.44 \\
\hline $\mathbf{T}_{\mathbf{8}}$ & 9.317 & 0.971 & 49.20 \\
\hline $\mathbf{S E}(\mathbf{m}) \mathbf{\pm}$ & 0.473 & $\mathrm{NS}$ & 2.29 \\
\hline $\mathbf{C D}(\mathbf{P} \leq \mathbf{0 . 0 5})$ & 1.436 & $\mathrm{NS}$ & 6.35 \\
\hline
\end{tabular}


Table.2 Effect of organic and inorganic nutrient sources on concentration and uptake of N, P and $\mathrm{K}$ by cabbage (Brassica oleracea L. var capitata) in acid inceptisol

\begin{tabular}{|c|c|c|c|c|c|c|}
\hline \multirow[t]{2}{*}{ Treatments } & \multicolumn{3}{|c|}{ Nutrient concentration (\%) } & \multicolumn{3}{|c|}{ Nutrient uptake (kg/ha) } \\
\hline & $\mathbf{N}$ & $\mathbf{P}$ & $\mathbf{K}$ & $\mathbf{N}$ & $\mathbf{P}$ & $\mathbf{K}$ \\
\hline$T_{1}$ & 3.17 & 0.35 & 2.49 & 65.25 & 7.20 & 52.26 \\
\hline $\mathbf{T}_{2}$ & 3.94 & 0.62 & 3.03 & 128.65 & 20.41 & 97.84 \\
\hline $\mathbf{T}_{3}$ & 3.31 & 0.41 & 2.63 & 89.34 & 10.47 & 71.05 \\
\hline $\mathbf{T}_{4}$ & 3.51 & 0.49 & 2.82 & 99.36 & 13.98 & 81.68 \\
\hline $\mathbf{T}_{5}$ & 3.85 & 0.63 & 3.04 & 124.41 & 20.65 & 99.25 \\
\hline $\mathbf{T}_{6}$ & 3.68 & 0.57 & 2.86 & 107.73 & 16.57 & 84.03 \\
\hline $\mathbf{T}_{7}$ & 4.15 & 0.67 & 3.13 & 150.79 & 24.18 & 113.45 \\
\hline $\mathbf{T}_{8}$ & 3.74 & 0.61 & 2.88 & 110.64 & 17.84 & 87.48 \\
\hline $\operatorname{SE}(m) \pm$ & 0.04 & 0.04 & 0.04 & 7.20 & 1.04 & 5.42 \\
\hline $\mathrm{CD}(\mathrm{P} \leq \mathbf{0 . 0 5})$ & 0.13 & 0.12 & 0.13 & 21.83 & 3.16 & 16.44 \\
\hline
\end{tabular}

Nutrients concentration and uptake by cabbage

Application of chemical fertilizers in combination with organic manures $\left(\mathrm{T}_{5}, \mathrm{~T}_{6}, \mathrm{~T}_{7}\right.$ and $\mathrm{T}_{8}$ ) increased the $\mathrm{N}, \mathrm{P}$ and $\mathrm{K}$ contents in cabbage over both sole application of organic manure and inorganic fertilizers $\left(\mathrm{T}_{2}, \mathrm{~T}_{3}, \mathrm{~T}_{4}\right)$ application as presented in table 2. Among the integrated treatments, the plot receiving $\mathrm{T}_{7}$ $(50 \% \quad \mathrm{RDF}+50 \% \quad \mathrm{~N} \quad \mathrm{VC})$ and $\mathrm{T}_{5} \quad(50 \%$ $\mathrm{RDF}+50 \% \mathrm{~N} \mathrm{VC})$ were found to be better combination in view of $\mathrm{N}, \mathrm{P}$ and $\mathrm{K}$ concentration and uptake over the treatment $\mathrm{T}_{6}$ and $\mathrm{T}_{8}$ which is attributed to lower $\mathrm{C}: \mathrm{N}$ ratio in vermicompost than Vermicompost (Ansari et $a l ., 2008)$. The per cent increase in nutrient concentration $\mathrm{N}, \mathrm{P}$ and $\mathrm{K}$ in $\mathrm{T}_{7}$ over $\mathrm{T}_{2}(100 \%$ $\mathrm{RDF}$ ) were 5.32, 8.06 and 3.03 per cent while the per cent increases in nutrient uptake $\mathrm{N}, \mathrm{P}$ and $\mathrm{K}$ in $\mathrm{T}_{7}$ over $\mathrm{T}_{2}(100 \% \mathrm{RDF})$ were 17.20 , 18.47 and 15.95 per cent, respectively. Higher uptake of $\mathrm{N}, \mathrm{P}$ and $\mathrm{K}$ in vegetative parts as reported in combined treatment might be due to good proliferation of root system, resulting in better absorption of in these plots. Similarly, positive influence of combination of inorganic and organic treatment has also been reported by Sharma and Sharma (2002); Gupta et al., (2006) and Singh et al., (2011).

In conclusion, the present investigation demonstrated that application of 50 per cent nitrogen through vermicompost along with 50 per cent of the recommended dose of nitrogenous fertilizer through urea $\left(\mathrm{T}_{7}\right)$ was found to be most effective in increasing yield, quality and nutrient concentration and uptake by cabbage as compared to sole application of organic manure or inorganic fertilizers indicating the best suitable option for production of quality cabbage in acid inceptisol of Meghalaya.

\section{Acknowledgement}

The laboratory facility provided by School of Natural Resource Management, CPGS, CAU, Umiam for carrying out soil and plant analysis for present study is duly acknowledged. 


\section{References}

Ansari, A.A., and Ismail, S.A. (2008). Report of $18^{\text {th }}$ World Congress of Soil Science. Philadelphia, Pennsylvania, USA, p. 23.

Bajpai, R.K., Chitale, S., Upadhyay, S.K. and Urkurkar, J.S. (2006). Long-term studies on soil physico-chemical properties and productivity of rice wheat system as influence by integrated nutrient management in inceptisol of Chhattisgarh. J. Indian Soc. Soil Sci., 54: 24-29.

Chaudhari, S.K. (2016). Soil Health in India: Retrospective and Perspective. In: Soil Health: Concept, Status and Monitoring: Katyal, J.C., Chaudhari, S.K., Dwivedi B.S., Biswas, D.R., Rattan, R.K., and Majumdar, K. (2016). ISSS Bulletin No. 30, National Agricultural Science Centre Complex, Pusa, New Delhi, pp. 34-52.

Gomez, K.A., and Gomez, A.A. (1984). Statistical Procedure for Agricultural Research. John Wiley and Sons, New York, p. 680.

Gupta, V., Sharma, R.S., and Vishvakarma, S.K. (2006). Long-term effect of integrated nutrient management on yield sustainability and soil fertility of rice (Oryza sativa)-wheat (Triticum aestivum) cropping system. Indian J. Agron., 51: 160-164.

Indian Horticulture Database. Ministry of Agriculture, Government of India, (2014). pp. 136-283.

Mohanty, B.K., and Hossain, M.M. (1998). A note on effects of nitrogen and phosphorus on cabbage (Brassica oleracea L. var. capitata). Orissa J.
Hortic., 26(1): 106-108.

Murali, M.K., and Setty, R.A. (2004).Effect of fertilizer, vermicompost and triacontanol on growth and yield of scented rice. Oryza, 4: 57-59.

Pande, J., and Singh, S. (2015). Effect of fertilizer, FYM and micronutrients on yield and quality of cabbage and soil fertility in Mollisol of Uttarakhand. Inter. J. Basic and appl. Agric. Res., 13(3): 432-436.

Pearson, O.H. (1931). Methods for determining the solidarity of cabbages. Hilgardia, 5: 383.

Sakal, R., Singh, A.P., R.P., and Bhogal, N.S. (1996). Twenty years of research on micro and secondary nutrients in soils and crops of Bihar. Res. Bull., Department of Soil Science, Faculty of Agriculture, R.A.U., Pusa, Samastipur Bihar.

Sharma, S.K., and Sharma, S.N. (2002). Integrated nutrient management for sustainability of rice (Oryza sativa)wheat (Triticum aestivum) cropping system. Indian J. Agric. Sci., 72: 573576.

Singh, M., Thakur, R., Sawarkar, S.D., and Vaishya, U.K. (2011). Impact of continuous use of inorganic fertilizers and organic manure on soil properties and productivity under soybean-wheat intensive cropping of a Vertisol. $J$. Indian Soc. Soil Sci., 59: 74-81.

Singh. B.K., Sharma. S.R., Kalia. P., and Singh. B. (2010).Character association and path analysis of morphological and economical traits in cabbage (Brassica oleracea var capitata). Indian J. Agric. Sci., 80(20): 116-118.

\section{How to cite this article:}

Chingak P.W. Konyak and Sanjay-Swami. 2018. Effect of Organic and Inorganic Nutrient Sources on Yield, Quality and Nutrient Uptake by Cabbage (Brassica oleracea L. var capitata) in Acid Inceptisol. Int.J.Curr.Microbiol.App.Sci. 7(07): 3035-3039. doi: https://doi.org/10.20546/ijcmas.2018.707.354 